\title{
States of mutation
}

\section{Re-configurations of modern state, business, and media*}

\author{
Estados de mutação \\ Reconfigurações do estado moderno, empresas e mídia
}

Laura L. Ortiz-Negrón**

\begin{abstract}
This article sets out an analysis of the transformations and new configurations between the state, business and media in Puerto Rico. The traditional demarcations between these three spheres are in flux as are their corresponding socio-political networks revealing new public and private scenarios. The state has managed downsizing via "partnership" initiatives with private enterprise and non-governmental organizations. Simultaneously, business has assumed a discourse of "social responsibility" participating in joint projects with the local state agencies and NGOs. The media's increasing involvement in social issues, in at times near independence of state generated directives, and at others, in direct concert with the state, is an important aspect of mediatic society. It shall be argued that the ever-increasing metamorphosis of mass media in tandem with other businesses, now constitute entities assuming roles previously filled exclusively by the state, and a concomitant transformation of the state resulting in the appearance a more mediatic-governmental entity. The new realignment of these spheres underline structural networks that reconfigure the world of the social and the public. In this sense we can identify contemporary social change, requiring re-conceptualization and analysis, as resulting from an emerging social configuration with fluid sociopolitical and cultural forms.
\end{abstract}

Keywords: Modern state; Media; Enterprises; Partnerships; Social responsibility

Resumo: O artigo analisa as transformações e novas configurações entre estado, empresas e mídia em Porto Rico. As demarcações tradicionais entre essas três esferas encontram-se em transformação, assim como suas redes sócio-políticas correspondentes, expondo novos cenários públicos e privados. O estado realizou um "enxugamento" mediante "parcerias" com empresas privadas e organizações não-governamentais.

* Paper presented at the First ISA Forum of Sociology - Sociological research and public debate, panel: new realities, new definitions: revisiting theories of communication, September 5-8, 2008, University of Barcelona, Spain. This topic forms part of my recent research project on the partnerships between government, business, and NGOs in Puerto Rico sponsored by the UPR-FIPI (Institutional Fund for Research).

** Researcher at the Social Science Research Center of the University of Puerto Rico, Río Piedras Campus; e-mail: 1lortiz@uprrp.edu

\begin{tabular}{|c|c|c|c|c|c|}
\hline Civitas & Porto Alegre & v. 9 & n. 1 & p. 9-18 & jan.-abr. 2009 \\
\hline
\end{tabular}


Simultaneamente, as empresas assumiram um discurso de "responsabilidade social", participando em projetos conjuntos com agências locais do estado e ONGs. O envolvimento crescente da mídia em temas sociais, em alguns momentos próximo da independência em relação às diretrizes estabelecidas pelo estado, em outros em parceria direta com o estado, é um aspecto importante da sociedade midiática. Argumenta-se que a crescente metamorfose das mídias em parceria com outras iniciativas privadas constitui-se entidades que assumem papéis exercidos anteriormente exclusivamente pelo estado, assim como uma transformação concomitante do estado, resultando aparentemente em uma entidade midiática-governamental. Os novos realinhamentos dessas esferas ensejam redes estruturais que reconfiguram o mundo social e público. Neste sentido, podemos identificar transformações sociais contemporâneas, exigindo novas conceitualizações e análises, resultando de uma configuração social emergente com formas sócio-políticas e culturais fluídas.

Palavras-chave: Estado moderno; Mídia; Empresas; Parcerias; Responsabilidade social

\section{Introduction}

When the modern state ceases to function as the guarantor of the public good and shifts its traditionally recognized, and legitimizing, responsibilities to private and semi-private/public entities, what implications for social analysis and policy can be identified? In this essay, I advance a critical analysis, on the basis of on certain contemporary transformations of three spheres of power - modern state, business, and media - in so far as these influence our experiences and understandings of the public and private. State-businessNGO partnerships (development triangle, third way-type politics), corporate social responsibility, and media economy, ${ }^{1}$ are key transformations for the new conditions of the public and the private. In this context, the traditional demarcations between these three spheres are in flux as are their corresponding socio-political networks disclosing new "public" and social scenarios. In what follows I seek to establish the new connections between them and to demystify much of the discursive arguments on these transformations such as inclusion, participation, community, social responsibility, and other promises.

\section{State transformations: "partnerships" and the "relational" state}

The politics of downsizing and "partnerships" constitute two governmental responses to the crisis of the modern state (Keynesian-welfare). ${ }^{2}$ Following the

\footnotetext{
${ }^{1}$ I define media economy as the production of discourses, images, and meanings together with its corresponding socioeconomic structuration.

2 The crisis of the modern state, in its fiscal dimension (debts, deficits), political problems (nationstate/globalization) and its economic change (industrial/post-industrial) commencing in the 1970s is the sociohistorical point of departure to analyze the present changes in the state sphere.
} 
experience of Puerto Rico, the policies of downsizing suppose a reduction of costs in the provision of services and programs provided by the state, whereby many services and projects are dispersed to NGOs or businesses through the assigning (contracts, subcontracts) of government funds. ${ }^{3}$ Within this scenario a strategic relation can be identified between a neoliberal state ${ }^{4}$ in the process of reconfiguring itself into what has been theorized as a "relational state", mediated through "partnerships" (alliances and projects between government, business, and NGOs. ${ }^{5}$ Likewise, it is recognized that the state no longer occupies the commanding height of society given the existence of a mediatized world. The emerging complex citizenship as a scaffolding for the relational state, admits a state and social citizenship to which collective social rights are produced on the basis of a symbolic code as a means for the articulation of organizational networks between the public and private. ${ }^{6}$ However, in so far as many of the "partnerships", in the case of Puerto Rico and the United States, rest upon the policies of downsizing, the discourse of "relational state" operates as a deployment of new values in the state-society relationship. A displacement can be observed from a Keynesian-welfare state to a "reduced ballast state". This state functions to maintain the buoyancy and growth of the economy while delegating social policy towards multiple entities. Nevertheless, it was found that this type of partnership discursively rests upon suppositions of a relational state, networks, cooperation, and mutual aid.

Empowered women, entrepreneurial communities and cooperation of private and public organizations are part of this new discourse. The strength of the discourse on the community, volunteering and citizen participation as the solution to diverse social problems is always already present in the discursive field of partnerships. ${ }^{7}$ The technologies of the self and common values'

3 The emitting of vouchers and the assignment of funding through competitive proposals and non-competitive ones are two of the more popular mechanisms employed in funding these partnerships.

4 The notion of neoliberal state is employed in a context of the policies of downsizing, the contraction of the agenda and publics by way of the adoption of diverse political and governmental strategies over the past decades. In this case, under consideration are partnerships that involve the delegation of services, projects and funds to private entities instead of governmental ones for the carrying out of traditionally state-managed functions.

5 Elaborations on the relational state can be found in the works of Pierpaolo Donati, Xavier Mendoza, Ysa Tamyko, and Alfred Vernis, among others.

6 Accordingly, the relational state should initiate all relational networks, establish alliances and generate synergies with social organization in order to respond to the necessities and social problems. In this sense, the relational state establishes the relations between the domains of the public and private, within the space of cooperation and co-responsibility among different sectors.

7 Henceforth, communities will be in charge of previously state provided social services through "partnerships" and also self-employment initiatives through business strategies. 
combine in order to produce the discursive effect of network productivity and concomitant social progress.

This notwithstanding, the economic nature of these "partnerships" are established on the basis of state funds funneled towards business and NGO. ${ }^{8}$ When examining this type of "partnership", its comportment and discourse consists of competition and the securing of funding. Likewise, the tertiary sector, from which the volunteer is drawn, incurs the costs of services derivative of partnerships, at bargain basement prices. Through these partnerships, it is the state that makes an investment in the services provided, however, these services are degraded, as are the conditions of work in the tertiary sector. ${ }^{9}$ I also found that some of the non-profit organizations that offer services, for example in the area of social services, are entities created by the island's dominant political parties with its implications of clientelism. ${ }^{10}$ Far from strengthening responsible, autonomous social subjects, this outsourcing of previously state run service and support provision actually results in an alienation from these non-governmental providers as their operational logic turns upon the logic of securing funding. The idea of co-responsibility operates as a discursive field that occludes the perception of a debilitated state, however, with increasing mechanisms for social control (technocratized biopolitics) and mediatically projected as a legitimate state. ${ }^{11}$

\section{Business and corporate social responsibility}

Within the context of globalization, increasing cases of corporate corruption, environmental crisis and a mediatized world, business has been transformed into a model based upon the notion of corporate social responsibility, which assume diverse modalities. ${ }^{12}$ From this perspective,

\footnotetext{
${ }^{8}$ In some cases the funds assigned to a business or contractor are channeled though the stock market for the emission of bonds permitting the business to obtain (tax credits). The economy functions thanks to the role of investor assumed by the State in more or less transparent fashion.

${ }^{9}$ The argument put forward by the government in Puerto Rico regarding the delegation of funding or subcontracting runs along the lines of "cost-effectiveness" as the state is unable to assume the work agenda that addressing the issue implies. However, there does not exist a single study that validates the cost-effective argument. The validation is achieved at a discursive level once enunciated, in effect: this is what there is, and the government is unable to do anything beyond outsourcing.

${ }^{10}$ Others were ambassadors for business that made contributions through some incentive or social problematic.

${ }^{11}$ The notion of biopolitics is employed here as indicating a form for the governing of populations or as a power over life.

${ }^{12}$ In Puerto Rico a non-profit organization was created named conectaRSE intended for the promotion of social responsibility in business.
} 
the processes, agenda and work cultures that have been articulated under a corporate image makes it more relevant given the context of a mediatic and globalized society. ${ }^{13}$ These corporate guidelines have been translated into programs, projects and services to communities with which these businesses interact, or may be influenced in some way. Under the contrivance of corporate social responsibility, specifically in the case of partnerships with government and NGOs, business is able to position itself in multi-polar fashion. On the one side, business assumes the discourse of co-responsibility and cooperation in its role and mediatic projection. Within the context of downsizing, business also competes, negotiates and absorbs state resources through contracts resulting from "partnerships".

Another variant of the partnership model is when a business decides to invest in a community project, at times making this investment through a NGO, which in turn is transformed into the company's ambassador. At the political level the image and survival of the NGO depends upon the company that subcontracted it. On the other hand, under the discourse of corporate social responsibility, the company places its employees as a labor pool of volunteers in communities or in mediatic campaigns. The volunteer labor of the company's employees is imposed as a condition of employment within a context of job insecurity and a mechanism for greater subjection of sociallabor to exploitation and oppression. In like manner, the word "community" is employed as a synonym for the economy. ${ }^{14}$ Another variant of the identity and amplification of the business agenda occurs when a company undertakes a social or cultural project of major mediatic or symbolic impact. ${ }^{15}$

The discourse of corporate social responsibility, business mediatization and "partnerships" with government and NGOs reconfigure the representation of the classical business enterprise into one which is in contact with, and attentive to, the social problems of the country, indeed, of the world. Following these new alliances and changed agendas, business is projected as a type of pseudostate.

\footnotetext{
${ }^{13}$ To these transformations are added the liberation of financial services, simple consolidation (industrial and financial) and the intersected consolidation (industrial financial and insurance) of corporations. Also, between architecture and the projection of customer service and culture, banks been able to strengthen was has been termed customer-centricity (Sheth, 2000).

${ }^{14}$ For example, as of the Community Reinvestment Act (12 CFR 25, et seq., 1977), that obligates the banking sector in the United States and its territories to promote banking services and resources for the local under-served communities and satisfy the credit needs of these communities. The idea of "community" and banking services are subsumed under the logic of inclusion/exclusion of the economic engine.

${ }^{15}$ In the case of Puerto Rico, the Banco Popular (Popular Bank) has marketed itself as promoter of national culture through the production of musical productions related to the unity of the Christmas season. The Banco Popular achieves greater relevance by its promotion of Puerto Rican culture, not to mention its already existing global markets.
} 


\section{Media and mediatization}

At present the capabilities of the media in the production of the real and the processes of massmediatization are key in the registering of the social and what constitutes "public" space. The innovations and technological convergence represented by the amplification of communicative agendas make the media a sphere of power capable of linking and assuming roles previously concentrated in the modern state. Simultaneously, the image, the simulation, and the screen, structure reality with overarching effects registered by spectators in new ways. Javier Esteinou Madrid describes this process of mediatic change as follows: "the technological revolution of the information media are transformed into the basic tools for the construction of the public and to act upon things public" (Estenou Madrid, 2002, p. 1).

In the context of mass culture, spectacularization and globalization, the communications media have been constituted as textual-discursive spaces that shape the attributes and understandings of the social world. The radicalness of mass culture and globalization consists of its implosion of the notion of culture (humanist, religious, and national) while it sustains what a culture is through its referents of practical and imaginary life. Globalization and its different meanings lead to a weakening of the frontiers between economy, culture and politics, in so far as different persons and sectors appropriate this communicative differential process in order to produce their interests at a local and planetary level, wherein global social relations are intensified. The signs and signification's that carry virtual texts rupture territorial geography and its corollary, the nation-state. From here stems the contingency and complexity in the formation of subjectivities and meanings of the social and the political. The actual and the virtual are simultaneously united and dislocated in order to go beyond the real as social bond. The massmediatization of all spheres of social life, in like manner, agglutinates all that is dispersed and separate in the world. From the talk show, reality show to the documentary and investigative journalism and other variants of infotainment are offered and function as organizers of mediatic spaces as the real. Therefore, the mediatic assumes primacy over the private and the real, which are simultaneously lodged within that space. This mediatic space unites all and goes on to constitute a center of political, social and cultural power. ${ }^{16}$ Public opinion is created by way of

\footnotetext{
${ }^{16}$ This technological power has in turn been registered as a sign of power of the media industry translated by multinational media conglomerates such as Murdoch, Viacom, Bertelsmann, Disney, Time Warner, Vivendi Universal, America Online, General Electric, Microsoft, Telefónica, and France Telecom.
} 
surveys, manufacturing the news and what comes to be known as the problem, and producing the private, as well as the use of such novel mechanisms as "hot lines" to attend to the problems of communities and citizens. In this sense, within the media a certain affinity with the state is created, and to a certain degree enters into competition with its traditional informational function. The media as a sign of "state" points no only towards an expansion of its communicative agenda to a social and public one, but also the arresting of citizens attention. The media as part of this new economy is produced as a new political-cultural force that unfolds in its diverse modalities "the real of the world" and organizes that which we call state, politics, society, culture and public space.

Given this state of affairs, it can be argued that a decomposition and re-articulation of the state, business, and media presupposes that the public space has been converted into a "relational", mediatic, and transparent space, where these three spheres intersect, carry out their new roles, and up to a certain point, are in a leveling position. The idea of "state" is transmuted, and in light of this, the need arises to reexamine the notions of responsibility, rights, demands, the public and the private. Two initial questions arise from these transformations: First, in what ways can we interrogate the discursive ideas of participation, cooperation, solidarity, and inclusiveness? Second, what kind of public space ${ }^{17}$ can be produced considering the realignment between the state, business, and media?

\section{References}

APPADURAI, Arjun. Difference and disjuncture in the global cultural economy: modernity at large cultural dimensions of globalization. Minneapolis: University of Minnesota Press, 1996.

BAUDRILLARD, Jean. La transparencia del mal: ensayo sobre los fenómenos extremos. Barcelona: Anagrama, 1991.

BAUMAN, Zygmunt. La sociedad individualizada. Madrid: Cátedra, 2001. . Modernidad líquida. Argentina: Fondo de Cultura Económica, 2003. . La sociedad sitiada. Argentina: Fondo de Cultura Económica, 2004.

BELL, Daniel. Cultural contradictions of capitalism. New York: Basic Books, 1976.

CAlleJO GAllego, Jaime. Procesos de estructuración social ante la pantalla. Revista Ris, v. 15, p. 59-93, 1996.

\footnotetext{
${ }^{17}$ Spaces that permit the convocation and fusion of different social groups, with their various claims, debates and agendas, in a manner that allow their articulation within these three spheres.
} 
CHOMSKY, Noam. El control de los medios de comunicación. Rebelión. 2004. Dowloaded in March, 2, 2007 at http://www.rebelion.org/noticia.php?id=1399.

COLOMÉ, Gabriel. Política y medios de comunicación: una aproximación teórica. Progress Report. Barcelona: Universidad Autónoma de Barcelona. n. 91, 1994.

DAVIS, Keith. An expanded view of the social responsibility of business. In: BEAUCHAMP T. L., BOWIE, N. E. (eds.). Ethical theory and business. Englewood Cliffs: Prentice-Hall, 1983, p. 94-97.

DEBORD, Guy. The state of spectacle. Semiotext E. New York, v. 3, n. 3, p. 96-99, 1980.

DONATI, Pierpaolo. Old and new family policies the perspective of relational sociology. Sociologia, Problemas e Práticas, v. 54, p.127-159, 2007. Downloaded in June 13, 2008 at http:/www.scielo.oces.mctes.pt/pdf/spp/n54/n54a07.pdf

ESTEINOU MADRID, Javier. Medios, primer poder. Etcétera. Mexico, 2002. Downloaded in December 2, 2006 at http://www.etcetera.com.mx/pag54ane21.asp

FOUCAULT, Michel. Tecnologías del yo y otros textos afines. Barcelona: Paidós, 1990.

FOX PIVEN, Frances; CLOWARD, Richard A.. The new class war: Reagan's attack on the welfare state and its consequences. New York: Pantheon Books, 1985.

GARCÍA CANCLINI, Néstor. Consumidores y ciudadanos: conflictos multiculturales de la globalización. Mexico: Grijalbo, 1995.

GONZÁLEZ REQUENA, Jesús; ORTIZ DE ZÁRATE, Amaya. El espot publicitario: las metamorfosis del deseo. Madrid: Cátedra, 1999.

HARTLEY, John. Los usos de la televisión. Barcelona: Paidós, 2000.

HELD, David. Democracy and globalization. working paper. Max Planck Institute for the Study of Societies. v. 97, n. 5, 1998. Downloaded in July 7, 2008 at http:/www. mpifg.de/pu/workpap/wp97-5/wp97-5.html

HERMAN, Edward S.; CHOMSKY, Noam. Manufacturing consent a propaganda model. New York: Pantheon Books, 1984.

HOSMER, LaRue T. Strategic planning as if ethics mattered. Strategic Management Journal, v. 15, n. 5, p. 17-34. 1994.

Trust: the connecting link between organizational theory and philosophical ethics. Academy of Management Review. New York, v. 20, n. 2, p. 379-403. 1995.

IBAÑEZ, Jesús. La publicidad: la tercera palabra de Dios. Revista de Occidente, v. 92, p. 73-96. 1989.

JESSOP, Bob. The capitalist state. New York: New York University Press, 1982.

. Narrating the future of the national economy and the national state: remarks on remapping regulation and reinventing governance. In: STEINMETZ, George (ed.). State/culture state formation after the cultural turn. Ithaca: Cornell University Press, 1999. p. 378-406. 
KING, J. E. A History of post Keynesian economics since 1936. Cheltenham: Edward Elgar, 2002.

LIPOVETSKY, Gilles. La era del vacío. ensayos sobre el individualismo contemporáneo. Barcelona: Anagrama, 1992.

LOGORIO, Carlos. Cultura sin sujeto: el dominio de la imagen en la posmodernidad. Buenos Aires: Biblos, 1988.

MARTINO, Bettina. Posmodernidad, crisis de representación y democracia electrónica. Razón y palabra. Mexico, 2001. Downloaded in December 7, 2006 at http://roai.mcu. es/en/consulta/registro.cmd?id=97230.

MENDOZA MAYORDOMO, Xavier. Las transformaciones del sector público en las sociedades avanzadas: del estado del bienestar al estado relacional. Papers de Formación, v. 23. Diputación de Barcelona. Downloaded in June 2008 at http://www. pv.ccoo.es/fsap/dipuvalencia/varis/Gestio/Sectpublico.htm

MUÑIZ VARELA, Miriam. Crisis económica y transformaciones sociales en Puerto Rico 1973-1983. San Juan: Centro de Investigaciones Sociales, UPR, 1986.

MURPHY, Tom. Web rules: how the internet is changing the way consumers make choices. Dearborn: Dearborn, 2000.

NEWCOMB, Horace. Television: the critical view. New York: Oxford University Press, 1976.

NÖTH, Winfried (ed.). Semiotics of the media. Berlin: Mouton de Gruyter, 1997.

O'CONNOR, James R. The fiscal crisis of the state. New York: St. Martin's Press, 1971.

ORTEGA, Enrique I. La comunicación publicitaria. Madrid: Pirámide, 1997.

ORTIZ-NEGRÓN, Laura L. Del estado a otros "estados": estudio en torno a las transformaciones contemporáneas en los roles, funciones y representaciones del gobierno, la empresa privada y los medios televisivos en Puerto Rico. Research Project. Institutional Fund for Research and Social Science Rsearch Center, University of Puerto Rico at Río Piedras Campus. 2007-2009.

PÉNINOU, Georges. Semiótica de la publicidad. Barcelona: Gustavo Pili, 1976.

PIERSON, Christopher. Beyond the welfare state? The new political economy of welfare. Pennsylvania: The Pennsylvania University Press, 1991.

RABOY, Marc; SOLERVICENS, Marcelo. Medios de comunicación. In: AMBROSI, Alain et al. (eds.). Palabras en juego. C \& F Éditions. 2005. Downloaded in December 5, 2006 at http://files.crisinfo.org/raboy.pdf

RISSOVER, Frederic; BIRCH David C. Mass media and the popular arts. New York: McGraw-Hill, 1983.

RIVERA, Jorge et. al. Governance choice for strategic corporate social responsibility: evidence from Central America. School of Business, The George Washington University. Working Papers. 2000. Downloaded in March 2, 2007 at http://www.gwu. edu/\%7Ebusiness/research/workingpapers/CentralAmerica.pdf 
RIVLIN, Alice M. Another state fiscal crisis: is there a better way? Washington, D.C.: The Brookings Institution, 2002.

ROOT, Jane. Open the box: about television. London: Comedia, 1986.

RUDING, H. Onno. The transformation of the financial services industry. Occasional Paper. Financial Stability Institute, v. 2, p. 1-24, 2002.

SHETH, Jagdish N. et al. The antecedents and consequences of customer-centric marketing. Journal of the Academy of Marketing Science. California, v. 28, n. 1, p. 55-66, 2000.

SPARKES, Russell. Socially responsible investment: a global revolution. John Wiley \& Sons, 2002.

SZTOMPKA, Piotr. The Sociology of social change. Oxford: Blackwell, 1994.

WERTHER, William B.; Chandler, David. Strategic corporate social responsibility: stakeholders in a global environment. London: Sage, 2004.

YSA, Tamyko. Governance forms in urban public-private partnerships. International Public Management Journal. Philadelphia, v. 10, n. 1, p. 35-57, 2007. 